\title{
Hubungan Motivasi Kerja dan Gaya Kepemimpinan Terhadap Kepuasan Kerja Karyawan
}

\author{
Sukma \\ Universitas Negeri Padang \\ Indonesia \\ E-mail : sukma980513@gmail.com
}

Ermita

Universitas Negeri Padang

Indonesia

E-mail : ermita@,fip.unp

\begin{abstract}
Abstrak
The purpose of this journal discussion is to analyze and prove work motivation and supportive leadership styles towards employee job satisfaction. The results of this study indicate how motivation and leadership style have significant positive thoughts on employee job satisfaction. Work motivation influences employee's performance. Leadership is an important factor in providing direction to the employee especially at this present moment in which transparency becomes essential. The leadership that is needed is leadership that can empower their employees. Leadership that can motivate employees is leadership that can foster a sense of confidence of the employees in carrying out their duties.
\end{abstract}

\section{Keywords-Motivasi kerja, gaya kepemimpina, kepuasan karyawan}

\section{Pendahuluan}

Kepuasan kerja adalah tingkat kesenangan yang dirasakan seseorang atas peranan atau pekerjaannya dalam organisasi. Tingkat rasa puas individu bahwa mereka mendapat imbalan yang setimpal dari bermacam-macam aspek situasi pekerjaan dari organisasi tempat mereka bekerja. Jadi kepuasan kerja menyangkut psikologis individu didalam organisasi, yang diakibatkan oleh keadaan yang ia rasakan dari lingkungannya. Hal yang dapat mempengaruhi kepuasan kerja karyawan yaitu motivasi keja dan gaya kepemimpinan.(Ermita, 2012)

Motivasi kerja adalah sebuah bentuk dorongan positif yang ditujukan kepada karyawan agar mereka terdorong dan memiliki semangat lagi dalam menjalankan pekerjaannya. Hal ini sangat berkaitan erat dengan kinerja karyawan dan hasil pekerjaan mereka. Bila mereka memiliki motivasi yang cukup kuat untuk terus melakukan pekerjaan di perusahaan dengan baik, maka hasil yang diperoleh juga akan baik. Pasti hal ini juga berdampak pada keberhasilan usaha yang sedang di jalankan.

Bukan hanya motivasi kerja yang dapat mempengaruhi kepuasan kerja, akan tetapi gaya kepemimpinan juga berpengaruh dalam kepuasan kerja karyawan. Gaya kepemimpinan adalah suatu cara, pola dan kemampuan tertentu yang digunakan oleh seorang pemimpin dalam bersikap, berkomunikasi dan berinteraksi untuk mempengaruhi, mengarahkan, mendorong dan mengendalikan orang lain atau bawahan agar bisa melakukan suatu pekerjaan sehingga mencapai suatu tujuan.

\section{Metode Penelitian}

Artikel ini disusun dengan metode dan langkah-langkah yang sistematis untuk memudahkan penulis dalam memaparkan hasil penelitian. Pada jurnal ini peneliti menggunakan metode studi literature dengan cara mengumpulkan literatur (bahan-bahan meteri) yang bersumber dari jurnal dan sumber lainnya yang berkaitan dengan Motivasi Kerja 
dan Gaya Kepemimpinan Terhadap Kepuasan Kerja Karyawan yang peneliti temukan dari perpustakaan dan jurnal yang telah ada. Setelah bahan kajian dikumpulkan, selanjutnya bahan tersebut dipelajari, kemudian penulis berusaha menyimpulkan dan menganalisis kembali bahan atau kajian yang telah dikumpulkan.

\section{KAJIAN TEORI DAN PEMBAHASAN}

\section{Motivasi}

Motivasi membahas bagaimana cara mengarahkan daya dan potensi yang dimiliki oleh karyawan sehingga karyawan mau bekerja sama secara produktif untuk mencapai dan mewujudkan tujuan yang telah ditentukan. Motivasi merupakan hal yang penting karena motivasi dapat menjadi penyebab, penyalur, maupun pendukung dari perilaku seseorang sehingga orang tersebut berkeinginan untuk bekerja keras dan antusias untuk mencapai hasil yang optimal. motivasi adalah sebuah suatu dorongan yang ditunjukan untuk memenuhi tujuan tertentu.(Susanty \& Baskoro, 2012)

Robbin mengemukakan bahwa motivasi adalah keinginan untuk melakukan sebagai kesediaan untuk mengeluarkan tingkat upaya yang tinggi untuk tujuan-tujuan organisasi, yang dikondisikan oleh kemampuan upaya itu untuk memenuhi suatu kebutuhan individual.

Siagian mengemukakan bahwa dalam kehidupan berorganisasi, termasuk kehidupan berkarya dalam organisasi bisnis, aspek motivasi kerja mutlak mendapat perhatian serius dari para manajer.

George dan Jones menyatakan bahwa unsurunsur motivasi kerja adalah sebagai berikut: (1) Arah perilaku (direction of behavior) Di dalam bekerja, ada banyak perilaku yang dapat dilakukan oleh karyawan. Arah perilaku (direction of behavior) mengacu pada perilaku yang dipilih seseorang dalam bekerja dari banyak pilihan perilaku yang dapat mereka jalankan baik tepat maupun tidak. Banyak contoh perilaku tidak tepat yang dapat dilakukan oleh seorang karyawan, perilakuperilaku ini nantinya akan menjadi suatu penghambat bagi organisasi dalam mencapai tujuannya. Sedangkan untuk mencapai tujuan perusahaan secara maksimal, karyawan harus memiliki motivasi untuk memilih perilaku yang fungsional dan dapat membantu organisasi dalam mencapai tujuannya. Setiap karyawan diharapkan dapat bekerja tepat waktu, mengikuti peraturan yang berlaku, serta kooperatif dengan sesame rekan kerja. (2) Tingkat usaha (level of effort) Tingkat usaha atau level of effort berbicara mengenai seberapa keras usaha seseorang untuk bekerja sesuai dengan perilaku yang dipilih. Dalam bekerja, seorang karyawan tidak cukup jika hanya memilih arah perilaku yang fungsional bagi pencapaian tujuan perusahaan. Namun, juga harus memiliki motivasi untuk bekerja keras dalam menjalankan perilaku yang dipilih. (3) Tingkat kegigihan (level of persistence) Hal ini mengacu pada motivasi karyawan ketika dihadapkan pada suatu masalah, rintangan atau halangan dalam bekerja, seberapa keras seorang karyawan tersebut terus berusaha untuk mrnjalankan perilaku yang dipilih. (Brahmasari \& Suprayetno, 2008)

\section{Gaya Kepemimpinan}

Gaya kepemimpinan adalah perilaku atau cara yang dipilih dan dipergunakan pemimpin dalam mempengaruhi pikiran, perasaan, sikap, dan perilaku para anggota organisasi atau bawahan. Hubungan pimpinan dan bawahan dapat diukur melalui penilaian pekerja terhadap gaya kepemimpinan para pemimpin dalam mengarahkan dan membina para bawahannya untuk melaksanakan pekerjaan. Secara spesifik, terdapat lima unsur utama yang merupakan esensi dari kepemimpinan, yaitu: (1) unsur pemimpin atau orang yang mempengaruhi (2) unsur orang yang dipimpin sebagai pihak yang dipengaruhi (3) unsur interaksi atau kegiatan/usaha dan proses mempengaruhi (4) unsur tujuan yang hendak dicapai dalam proses mempengaruhi dan (5) unsur perilaku/kegiatan yang dilakukan sebagai hasil mempengaruhi. (Susanty \& Baskoro, 2012)

Jeni-jenis gaya kepemimpinan menurut Hasibuan (2014) mengemukakan ada tiga, (1) gaya kepemimpinan otoriter, adalah jika 
kekuasaan atau wewenang, sebagian besar mutlak tetap berada pada pimpinan atau kalau pimpinan itu menganut sistem sentralisasi wewenang. Pengambilan keputusan dan kebijaksanaan hanya ditetapkan sendiri oleh pemimpin, bawahan tidak diikutsertakan untuk memberikan saran, ide, dan pertimbangan dalam proses pengambilan keputusan. (2) kepemimpinan partisipasi, adalah apabila dalam kepemimpinan-nya dilakukan dengan cara persuasif, menciptakan kerja sama yang serasi, menumbuhkan loyalitas, dan partisipasi para bawahan. Pemimpin memotivasi bawahan agar merasa ikut memiliki perusahaan. Bawahan harus berpartisipasi memberikan saran, ide, dan pertimbangan dalam proses pengambilan keputusan. (3) kepemimpinan delegasi, apabila seorang pemimpin mendelegasikan wewenangnya kepada bawahan dengan agak lengkap. Dengan demikian, bawahan dapat mengambil keputusan dan kebijaksanaan dengan bebas atau leluasa dalam melaksanakan pekerjaannya. Pemimpin tidak peduli cara bawahan mengambil keputusan dan mengerjakan pekerjaannya, sepenuhnya diserahkan kepada bawahan.

Sedangkan menurut Sutikno mengemukakan ada tujuh gaya kepemimpinan, (1) otokratik, Tipe kepemimpinan menganggap bahwa kepemimpinan adalah hak pribadinya (pemimpin), sehingga ia tidak perlu berkonsultasi dengan orang lain dan tidak boleh ada orang lain yang turut campur. Seorang pemimpin otokratik akan menunjukkan sikap yang menonjolkan keakuannya, dan selalu mengabaikan peranan bawahan dalam proses pengambilan keputusan, tidak mau menerima saran dan pandangan bawahannya. (2) laisez faire, Tipe kepemimpinan ini merupakan kebalikan dari tipe kepemimpinan otokratik. Dalam kepemimpinan tipe ini sang pemimpin biasanya menunjukkan perilaku yang pasif dan seringkali menghindar diri dari tanggung jawab. Seorang pemimpin yang kendali bebas cenderung memilih peran yang pasif dan membiarkan organisasi berjalan menurut temponya sendiri. Disini seorang pemimpin mempunyai keyakinan bebas dengan memberikan kebebasan yang seluas-luasnya terhadap bawahan maka semua usahanya akan cepat berhasil. (3) paternalistic, Persepsi seorang pemimpin yang paternalistik tentang peranannya dalam kehidupan organisasi dapat dikatakan diwarnai oleh harapan bawahan kepadanya. Harapan bawahan berwujud keinginan agar pemimpin mampu berperan sebagai bapak yang bersifat melindungi dan layak dijadikan sebagai tempat bertanya dan untuk memperoleh petunjuk, memberikan perhatian terhadap kepentingan dan kesejahteraan bawahannya. (4) kharismatik, Seorang pemimpin yang kharismatik memiliki karakteristik khusus yaitu daya tariknya yang sangat memikat, sehingga mampu memperoleh pengikut yang sangat besar dan para pengikutnya tidak selalu dapat menjelaskan secara konkrit mengapa orang tersebut itu dikagumi. (5) militeristik, Pemimpin yang bertipe militeristik ialah pemimpin dalam menggerakkan bawahannya lebih sering mempergunakan sistem perintah, senang bergantung kepada pangkat dan jabatannya, dan senang kepada formalitas yang berlebih-lebihan Menuntut disiplin yang tinggi dan kaku dari bawahannya, dan sukar menerima kritikan dari bawahannya. (6) pseudo-demokratik, Tipe ini disebut juga kepemimpinan manipulatif atau semi demokratik. Pemimpin seperti ini menjadikan demokrasi sebagai selubung untuk memperoleh kemenangan tertentu. Pemimpin yang bertipe pseudo-demokratik hanya tampaknya saja bersikap demokratis padahal sebenarnya dia bersikap otokratis. Pemimpin ini menganut demokrasi semu dan lebih mengarah kepada kegiatan pemimpin yang otoriter dalam bentuk yang halus dan samar-samar. (7) demokratik, Tipe demokratik adalah tipe pemimpin yang demokratis, dan bukan karena dipilihnya si pemimpin secara demokratis. Tipe kepemimpinan dimana pemimpin selalu bersedia menerima dan menghargai saran-saran, pendapat, dan nasihat dari staf dan bawahan, melalui forum musyawarah untuk mencapai kata sepakat. Kepemimpinan demokratik adalah kepemimpinan yang aktif, dinamis, dan terarah. Kegiatan-kegiatan pengendalian dilaksanakan secara tertib dan bertanggung jawab. 


\section{Kepuasan Kerja}

Menurut Blum dalam As'ad kepuasan kerja merupakan sikap umum yang merupakan hasil dari beberapa sikap khusus terhadap factorfaktor pekerjaan, penyesuaian diri dan hubungan individu di luar kerja. Sedangkan menurut Handoko kepuasan kerja atau job satisfaction adalah keadaan emosional yang menyenangkan atau tidak menyenangkan dengan mana para karyawan memandang pekerjaan mereka. Sebuah perusahaan sangat bergantung pada karyawannya, sebagaimana baiknya sebuah perencanaan namun pelaksanaan akan tetap bergantung pada manusia yang menjalankannya sehingga hasil sebenarnya akan juga menggambarkan kepuasan kerja karyawan tersebut. Ini menunjukkan pula bahwa semakin tinggi kepuasan kerja karyawan, maka makin tinggi pula prestasi kerja yang ditampilkan, begitu juga sebaliknya. Karyawan yang mempunyai prestasi yang baik akan menuntut imbalan yang sesuai dengan hasil yang dicapainya.

Kepuasan kerja juga memiliki hubungan yang erat dengan sikap karyawan atas pekerjaan mereka, situasi kerja setiap harinya, kerjasama antar karyawan baik dengan atasan maupun dengan rekan kerja. Kepuasan kerja secara lebih jauh, juga menunjukkan kesesuaian antara sebuah harapan terhadap pekerjaan yang ada dan imbalan yang diperoleh dari pekerjaan tersebut. Dari beberapa definisi dan penjelasan diatas maka dapat ditarik kesimpulan bahwa kepuasan kerja merupakan refleksi dari seorang karyawan terhadap pekerjaannya yang timbul bukan hanya sebagai hasil interaksi antara karyawan dengan pekerjaannya, tetapi juga dengan lingkungan kerja, situasi dan kondisi kerja serta rekan kerja karyawan.

Faktor-faktor kepuasan kerja yang diambil berdasarkan pada Job Descriptive Index, dimana terdapat pengukuran yang standar terhadap kepuasan kerja, yang meliputi beberapa faktor yaitu pekerjaan itu sendiri, mutu dan pengawasan supervisi, gaji atau upah, kesempatan promosi, dan rekan kerja. Job Description Index adalah pengukuran terhadap kepuasan kerja yang dipergunakan secara luas. Riset menunjukkan bahwa Job Description
Index dapat menyediakan skala kepuasan kerja yang valid dalam skala yang dapat dipercaya (1)Pekerjaan itu sendiri, Setiap karyawan lebih menyukai pekerjaan yang memberikan peluang kepada mereka untuk menggunakan ketrampilan dan kemampuan yang dimiliki, yang mampu menawarkan satu varietas tugas, kebebasan dan umpan balik tentang seberapa baiknya mereka dalam melakukan hal tersebut. Karakteristik tersebut membuat pekerjaan menjadi lebih menantang secara mental. (2)Mutu Pengawasan Supervisi, Kegiatan pengawasan merupakan suatu proses dimana seorang manajer dapat memastikan bahwa kegiatan yang dilakukan oleh karyawannya sesuai dengan apa yang telah direncanakan sebelumnya. Proses pengawasan mencatat perkembangan pekerjaan yang telah dilakukan oleh karyawan sehingga memungkinkan manajer untuk dapat mendeteksi adanya penyimpangan dari apa yang telah direncanakan dengan hasil saat ini, dan kemudian dapat dilakukan tindakan pembetulan untuk mengatasinya. (3) Gaji atau Upah, Karyawan selalu menginginkan sistem penggajian yang sesuai dengan harapan mereka. Apabila pembayaran tersebut tampak adil berdasarkan pada permintaan pekerjaan, tingkat ketrampilan individu, dan standar pembayaran masyarakat pada umumnya, maka kepuasan yang dihasilkan akan juga tinggi. (4) Kesempatan Promosi, Promosi merupakan perpindahan dari suatu jabatan ke jabatan yang lain dimana jabatan tersebut memiliki status dan tanggung jawab yang lebih tinggi. Hal ini memberikan nilai tersendiri bagi karyawan, karena merupakan bukti pengakuan terhadap prestasi kerja yang telah dicapai oleh karyawan. Promosi juga memberikan kesempatan untuk pertumbuhan pribadi, untuk lebih bertanggung jawab dan meningkatkan status sosial. (5) Rekan Kerja, Manusia merupakan makhluk sosial yang membutuhkan interaksi dengan orang lain, begitu juga dengan karyawan di dalam melakukan pekerjaannya membutuhkan interaksi dengan orang lain baik rekan kerja maupun atasan mereka. (Kartika \& Kaihatu, 2010) 


\section{Hubungan motivasi dengan kepuasan kerja}

Karyawan yang termotivasi dan kepuasannya tinggi, membentuk sebuah keadaan yang ideal, baik bagi perusahaan maupun karyawan itu sendiri. Keadaan ini dapat terjadi bila ada kesamaan antara harapan karyawan dan perusahaan dengan keadaan nyata saat ini, dimana di satu sisi perusahaan menemukan kondisi karyawan yang dapat bekerja dengan baik dan mencapai tujuan perusahaan, sedangkan karyawan menemukan kondisi bahwa segala harapan mereka berkaitan dengan karir, gaji telah diberikan oleh perusahaan. Semakin tinggi faktor-faktor motivasi yang diberikan maka akan semakin tinggi pula kepuasan kerja pegawai.

\section{Hubungan gaya kepemimpinan dengan kepuasan kerja}

Perilaku atasan juga merupakan determinan utama dari kepuasan. Umumnya kepuasan dapat ditingkatkan, bila atasan bersifat ramah dan memahami, menawarkan pujian untuk kinerja yang baik, mendengarkan pendapat karyawan, dan menunjukkan suatu minat pribadi pada mereka. Partisipasi dalam pengambilan keputusan kepemimpinan khususnya pada kepemimpinan demokratis akan mempunyai dampak pada peningkatan hubungan manajer dengan bawahan, menaikkan moral dan kepuasan kerja serta menurunkan ketergantungan terhadap pemimpin. Dengan demikian dapat dikatakan kepemimpinan sangat erat hubungannya dengan kepuasan kerja karyawan. Kepemimpinan yang memperoleh respon positif dari karyawan cenderung akan meningkatkan kepuasan kerja karyawan, demikian bila terjadi sebaliknya.

\section{KESIMPULAN}

Motivasi kerja merupakan proses yang menyebabkan seseorang berperilaku dengan cara tertentu dalam rangka memenuhi kebutuhan yang sangat individu untuk bertahan hidup, keamanan, kehormatan, pencapaian, kekuasaan, pertumbuhan dan rasa harga diri.
Gaya kepemimpinan adalah perilaku atau cara yang dipilih dan dipergunakan pemimpin dalam mempengaruhi pikiran, perasaan, sikap, dan perilaku para anggota organisasi atau bawahan. Hubungan pimpinan dan bawahan dapat diukur melalui penilaian pekerja terhadap gaya kepemimpinan para pemimpin dalam mengarahkan dan membina para bawahannya untuk melaksanakan pekerjaan.

Kepuasan kerja atau job satisfaction adalah keadaan emosional yang menyenangkan atau tidak menyenangkan dengan mana para karyawan memandang pekerjaan mereka.

\section{Daftar Pustaka}

Brahmasari, I. A., \& Suprayetno, A. (2008). Pengaruh Motivasi Kerja , Kepemimpinan dan Budaya Organisasi Terhadap Kepuasan Kerja Karyawan serta Dampaknya pada Kinerja Perusahaan ( Studi kasus pada PT . Pei Hai International Wiratama Indonesia ). Jurnal Manajemen Dan Kewirausahaan, 10(2), 124-135.

Ermita. (2012). Hubungan Antar Manusia dan Semangat Kerja Pegawai. PEDAGOGI, Jurnal Ilmiah Ilmu Pendidikan, XII(2), 7081.

Kartika, E. W., \& Kaihatu, T. S. (2010). Analisis Pengaruh Motivasi Kerja Terhadap Kepuasan Kerja ( Studi Kasus pada Karyawan Restoran di Pakuwon Food Festival Surabaya ). Jurnal Manajemen Dan Kewirausahaan, 12(1), $100-112$.

Susanty, A., \& Baskoro, S. W. (2012). Pengaruh Notivasi Kerja Dan Gaya Kepemimpinan Terhadap Disiplin Kerja Serta Dampaknya Pada Kinerja Karyawan (Studi Kasus Pada PT. PLN (Persero) APD Semarang. Jurnal Teknik Industri, VII(2), 77-84. 